\title{
Studies on physico-chemical quality of peanut paneer prepared from the admixture of peanut (Arachis hypogaea L.) milk and skimmed milk
}

\author{
J.DAVID
}

\begin{abstract}
An investigation was carried out with an attempt to develop Peanut Paneer by partial addition of Peanut milk and skim milk. For control, $\left(\mathrm{T}_{0}\right)$ Peanut milk was standardized to 6 per cent fat and 9 per cent SNF and treatment $\left(\mathrm{T}_{1}\right)$ was standardized to a ratio of 50:50 (PM:SM), $\mathrm{T}_{2}$ 60:40 (PM:SM) and $\mathrm{T}_{3}$ (70:30) (PM:SM). The Peanut Paneer samples of different treatments were analyzed for physico-chemical properties (moisture, protein, fat, carbohydrate and ash), its nutritional content and organoleptic characteristics (colour and appearance, body and texture, flavour and taste) by trained panelist using 9 point hedonic scale. Microbiological analysis was carried out to assess the shelf-life of the best treatments by SPC and coliform test. Analysis revealed that the product conform to the legal standard as per PFA. Thus, as far as product acceptability judged by organoleptic evaluation and therapeutic value, the treatment can be rated as $\mathrm{T}_{2}>\mathrm{T}_{1}>\mathrm{T}_{0}>\mathrm{T}_{3}$.
\end{abstract}

KEY WORDS : Peanut milk, Skimmed milk, Peanut paneer

HOW TO CITE THIS PAPER : David, J. (2015). Studies on physico-chemical quality of peanut paneer prepared from the admixture of peanut (Arachis hypogaea L.) milk and skimmed milk. Res. J. Animal Hus. \& Dairy Sci., 6(2) : 121-124.

J. David, Department of Dairy Technology, Sam Higginbottom Institute of Agriculture, Technology and Sciences, ALLAHABAD (U.P.) INDIA

Email : profjohndavid06@gmail.com 